\title{
Life and death in the Chicxulub impact crater: a record of the Paleocene-Eocene Thermal Maximum
}

Vann Smith $^{1,2}$, Sophie Warny ${ }^{1,2}$, Kliti Grice ${ }^{3}$ Bettina Schaefer $^{3}$, Michael T. Whalen ${ }^{4}$, Johan Vellekoop ${ }^{5,6}$, Elise Chenot ${ }^{7}$, Sean P. S. Gulick ${ }^{8,9,10}$, Ignacio Arenillas ${ }^{11}$, Jose A. Arz ${ }^{11}$, Thorsten Bauersachs ${ }^{12}$, Timothy Bralower ${ }^{13}$, François Demory ${ }^{14}$, Jérôme Gattacceca ${ }^{14}$, Heather Jones ${ }^{13}$, Johanna Lof ${ }^{15}$, Christopher M. Lowery ${ }^{9}$, Joanna Morgan $^{16}$, Noelia B. Nuñez Otaño ${ }^{17}$, Jennifer M. K. O'Keefe ${ }^{18}$, Katherine O'Malley ${ }^{4}$, Francisco J. Rodríguez-Tovar ${ }^{19}$, Lorenz Schwark ${ }^{3,12}$, and the IODP-ICDP Expedition 364 Scientists ${ }^{+}$

${ }^{1}$ Department of Geology and Geophysics, Louisiana State University, Baton Rouge, LA 70803, USA

${ }^{2}$ Museum of Natural Science, Louisiana State University, Baton Rouge, LA 70803, USA

${ }^{3}$ Western Australian Organic and Isotope Geochemistry Centre, The Institute for Geoscience Research,

School of Earth and Planetary Science, Curtin University, Perth, WA 6102, Australia

${ }^{4}$ Department of Geosciences, University of Alaska Fairbanks, Fairbanks, AK 99775, USA

${ }^{5}$ Department of Earth and Environmental Sciences, Division of Geology, KU Leuven, 3001 Heverlee, Belgium

${ }^{6}$ Analytical, Environmental and Geo-Chemistry (AMGC), Vrije Universiteit Brussel, 1050 Brussels, Belgium

${ }^{7}$ Institut Polytechnique Lasalle Beauvais, 19 Rue Pierre Waguet, BP 30313, 60026 Beauvais, France

${ }^{8}$ Department of Geological Sciences, Jackson School of Geosciences, University of Texas at Austin, TX 78712, USA

${ }^{9}$ Institute for Geophysics, Jackson School of Geosciences, University of Texas at Austin, TX 78712, USA

${ }^{10}$ Center for Planetary Systems Habitability, University of Texas at Austin, TX 78712, USA

${ }^{11}$ Departamento de Ciencias de la Tierra e Instituto Universitario de Investigación de Ciencias Ambientales de Aragón,

Universidad de Zaragoza, Pedro Cerbuna 12, 50009 Zaragoza, Spain

${ }^{12}$ Department of Organic Geochemistry, Institute of Geosciences, Christian Albrechts University, 24118 Kiel, Germany

${ }^{13}$ Department of Geosciences, Pennsylvania State University, University Park, PA 16801, USA

${ }^{14}$ CNRS, Aix-Marseille Univ, IRD, Coll France, INRAE, CEREGE, Aix-en-Provence, France

${ }^{15}$ Géosciences Montpellier, l'Université Montpellier, CNRS, Montpellier, France

${ }^{16}$ Department of Earth Science and Engineering, Imperial College London, SW7 2AZ, UK

${ }^{17}$ Facultad de Ciencia y Tecnología (FCyT), Universidad Autónoma de Entre Ríos, CONICET,

Laboratorio de Geología del Neógeno-Cuaternario, Diamante, Entre Ríos, Argentina

${ }^{18}$ Department of Physics, Earth Science, and Space Systems Engineering, Morehead State University, Morehead, KY, USA

${ }^{19}$ Departamento de Estratigrafía y Paleontología, Facultad de Ciencias, Universidad de Granada, 18002 Granada, Spain

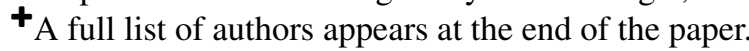

Correspondence: Vann Smith (vannpaleo@gmail.com)

Received: 4 April 2020 - Discussion started: 18 May 2020

Revised: 13 August 2020 - Accepted: 1 September 2020 - Published: 19 October 2020

Abstract. Thermal stress on the biosphere during the extreme warmth of the Paleocene-Eocene Thermal Maximum (PETM) was most severe at low latitudes, with sea surface temperatures at some localities exceeding the $35^{\circ} \mathrm{C}$ at which marine organisms experience heat stress. Relatively few equivalent terrestrial sections have been identified, and the response of land plants to this extreme heat is still poorly understood. Here, we present a new record of the PETM from the peak ring of the Chicxulub impact crater that has been identified based on nannofossil biostratigraphy, an acme of the dinoflagellate genus Apectodinium, and a negative carbon isotope excursion. Geochemical and microfossil proxies show that the PETM is marked by elevated $\mathrm{TEX}_{86}^{\mathrm{H}}$-based sea surface temperatures (SSTs) averaging $\sim 37.8^{\circ} \mathrm{C}$, an in- 
crease in terrestrial input and surface productivity, salinity stratification, and bottom water anoxia, with biomarkers for green and purple sulfur bacteria indicative of photic zone euxinia in the early part of the event. Pollen and plants spores in this core provide the first PETM floral assemblage described from Mexico, Central America, and the northern Caribbean. The source area was a diverse coastal shrubby tropical forest with a remarkably high abundance of fungal spores, indicating humid conditions. Thus, while seafloor anoxia devastated the benthic marine biota and dinoflagellate assemblages were heat-stressed, the terrestrial plant ecosystem thrived.

\section{Introduction and geologic setting}

The Paleocene-Eocene Thermal Maximum (PETM) was a period of global warming associated with ocean acidification, an intensified hydrological cycle, a reduction in marine dissolved oxygen concentrations, eustatic sea level rise, and major ecological shifts (e.g., Zachos et al., 2003; Gingerich 2006; Dickson et al., 2014; Sluijs et al., 2008; Carmichael et al., 2017). Recent age estimates place the PETM at approximately 55.93-55.71 Ma (Westerhold et al., 2017; Hollis et al., 2019). The onset of the PETM is marked by a global negative carbon isotope excursion (CIE) (Dickens et al., 1997; Gradstein et al., 2012). Possible sources of this isotopically light carbon include methane clathrates, combustion of organic matter, thermogenic methane, and organic matter released from permafrost (e.g., McInerney and Wing, 2011). Sea surface temperature (SST) during the PETM in some low-latitude regions exceeded $35^{\circ} \mathrm{C}$, resulting in heat stress for eukaryotic plankton (e.g., Frieling et al., 2018). In contrast, the few existing PETM records of low-latitude terrestrial plant assemblages indicate an increase in diversity (e.g., Jaramillo et al., 2010; Srivastava and Prasad, 2015; Prasad et al., 2018). Here, we established a new multiproxy record of the response of marine and terrestrial biota to the PETM in the western Caribbean and Gulf of Mexico at the International Ocean Discovery Program (IODP) Expedition 364 Site M0077. This record includes the first published pollen and spore PETM assemblage from tropical North America (Smith et al., 2020a, b). These data allow us to determine the extent of marine and terrestrial heat stress from the understudied region and determine how they compare with other PETM sections.

International Ocean Discovery Program-International Continental Scientific Drilling Program (IODP-ICDP) Site M0077 is located on the peak ring of the Chicxulub impact crater in the Yucatán Peninsula, Mexico (Fig. 1) (Morgan et al., 2017). The crater was a marine basin in the Paleogene, with mainly pelagic and outer-platform sediment deposition (Lefticariu et al., 2006). Immediately after impact, some of the rim may have been subaerially emergent (Morgan et al., 1997) but if so would have been quickly eroded. During the PETM, only isolated areas of the crater rim may have been emergent, given the existence of an embayment into the crater to the north and northeast (Gulick et al., 2008). Although PETM records from the Gulf of Mexico are scarce, another site in the Chicxulub crater, the Yaxcopoil-1 (Yax-1) core, contains a PETM section identified by a negative carbon isotope excursion, deposited during a period of maximum flooding (Whalen et al., 2013) (Fig. 1). The PETM has also been identified on the Mississippi paleo-shelf (Fig. 1), where evidence indicates increased $\mathrm{TEX}_{86}^{\mathrm{H}}$-based SSTs, photic zone euxinia, and sea level rise (Sluijs et al., 2014).

\section{Methods}

Quantitative palynological abundances are expressed in terms of specimens per gram using a Lycopodium spike. Species counts, descriptions, and paleoecological interpretations can be found in Smith et al. (2020a, b). The D / S ratio between dinoflagellate cysts and pollen-plant spores is described in Warny et al. (2003). The degree of bioturbation has been quantified using the bioturbation index (BI) (Taylor and Goldring, 1993), a descriptive classification ranging from 0 (no bioturbation) to 6 (completely bioturbated). Samples for $\delta^{15} \mathrm{~N}$ and $\delta^{13} \mathrm{C}_{\mathrm{TOC}}(n=65)$ analyses were prepared by acidifying approximately $0.5 \mathrm{~g}$ of powdered material with an excess of $1 \mathrm{M} \mathrm{HCl}$. The acid-insoluble residues were neutralized, freeze-dried, and analyzed for their carbon and nitrogen contents as well as stable isotope compositions using a Costech elemental analyzer (ECS 4010) and a Delta + XP mass spectrometer. Typical instrumental precision of the isotope measurements is $<0.2 \%$. $\delta^{15} \mathrm{~N}$ is reported relative to atmospheric $\mathrm{N}_{2}$, and $\delta^{13} \mathrm{C}_{\mathrm{TOC}}$ is reported relative to $\mathrm{Vi}$ enna Pee Dee Belemnite (VPDB). Clay mineral assemblages were identified by X-ray diffraction on oriented mounts of noncalcareous clay-sized particles $(<2 \mu \mathrm{m})$. SSTs based on isoprenoidal glyceroldialkylglyceroltetraethers (isoGDGTs) (Schouten et al., 2002) were reconstructed using the TEX $\mathrm{H}_{86}^{\mathrm{H}}$ calibration of Kim et al. (2010). Palynological sampling resolution is approximately $5 \mathrm{~cm}$, and $\delta^{15} \mathrm{~N}$ and $\delta^{13} \mathrm{C}_{\mathrm{TOC}}$ sampling resolution approximately $0.5 \mathrm{~cm}$, in the body of the PETM section. Biomarker analysis in the late Paleocene section was hampered by low total organic carbon (TOC), with only one sample suitable for TEX 86 measurement. Generally, the sampling strategy was designed for high-resolution analysis of the body of the PETM section, which appears to be bounded at the top and bottom by unconformities. Additional methods are provided in the Supplement along with all data.

\section{Results}

IODP-ICDP drilling at Site M0077 recovered Paleocene to early Eocene post-impact sedimentary rocks between 617.33 and $505.70 \mathrm{~m}$ below the seafloor (m b.s.f.). The PETM section (607.27-607.06 mb.s.f., Core 37R-1) is a laminated 


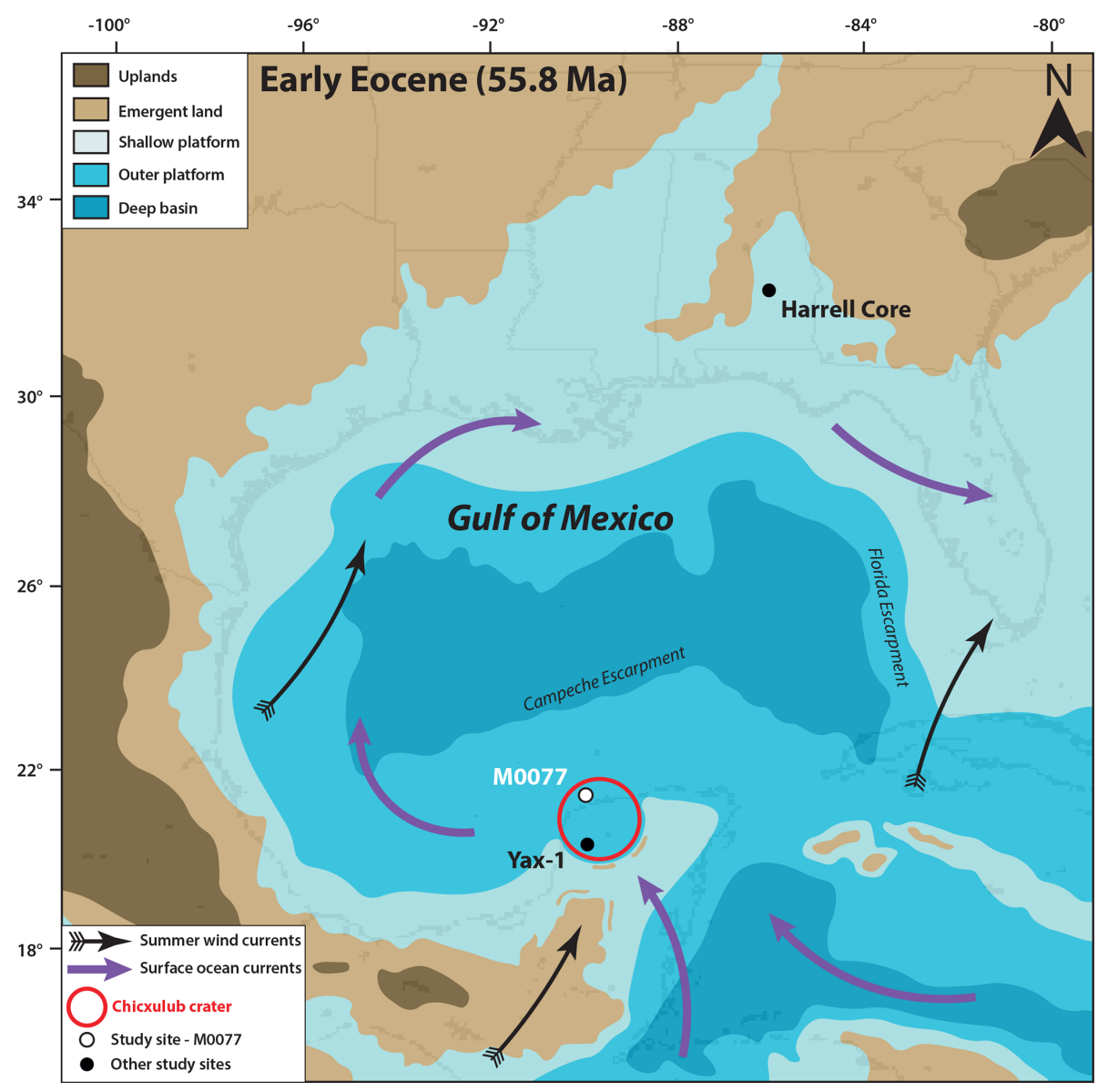

Figure 1. Paleocene-Eocene Thermal Maximum (55.8 Ma) paleogeography of the Gulf of Mexico and surrounding regions (modified from Scotese and Wright, 2018), with locations of Site M0077 (IODP 364), Yax-1 (Whalen et al., 2013), and the Harrell Core in east-central Mississippi (Sluijs et al., 2014). The Harrell Core location has been adjusted to match the paleo-latitude and longitude at the PETM. Surface ocean currents and summer wind fields are from Winguth et al. (2010).

black to dark gray shale separated from an upper Paleocene carbonate hardground by an unconformity and unconformably underlying a burrowed lower Eocene packstone at the top of Core 37R-1 and through Core 36R-4 (Fig. 2). The uppermost Paleocene, underlying the PETM interval, is characterized by two significant disconformities. The lower disconformity is atop a $6-8 \mathrm{~cm}$ thick gray claystone (607.68 mb.s.f.) interpreted to be a bentonite, with an erosionally scoured upper surface. It is overlain by a $7 \mathrm{~cm}$ thick carbonate rudstone (607.68-607.61 mb.s.f.) that grades upward into a $22 \mathrm{~cm}$ thick packstone (607.61-607.39 mb.s.f.). The rudstone contains claystone and carbonate lithoclasts up two $2 \mathrm{~cm}$ in diameter, foraminifera, and lime mud, and it grades into a light gray foraminiferal packstone with wispy stylolitic laminae. The packstone is overlain by a $\sim 4 \mathrm{~cm}$ thick gray claystone (607.39-607.35 mb.s.f.). Both the contact between the packstone and claystone and the claystone itself are burrowed, and one burrow is infilled by material from the overlying facies. The claystone is abruptly overlain by a carbonate grainstone (607.32-607.27 mb.s.f.) with planktic and large benthic foraminifera, red algae, ostracods, calcispheres, and black and gray carbonate lithoclasts. The top of this unit ( $607.27 \mathrm{mb}$.s.f.) is a hardground and disconformity with about $1 \mathrm{~cm}$ of relief, which separates the Paleocene and PETM sections. The lower contact of the grainstone with the underlying claystone (607.32 m b.s.f.) also appears to be unconformable, but no biozones are missing, so it may represent a diastem rather than a significant hiatus.

The PETM interval (607.27-607.06 mb.s.f.) is about $21 \mathrm{~cm}$ thick. It has a sharp basal contact that drapes over the relief atop the underlying hardground. The PETM interval consists of dark gray to black shale that is laminated at the millimeter scale. The base of the interval is slightly lightercolored gray shale and contains clay, organic matter, sandsized carbonate lithoclasts and foraminifera eroded from the underlying unit, as well as rare green grains and spherules that appear to be altered impact glass. The remainder of the PETM interval consists of millimeter-scale laminae that are usually dark gray at their base, black at the top, and contain quartz, muscovite, rare plagioclase silt grains, and rare 


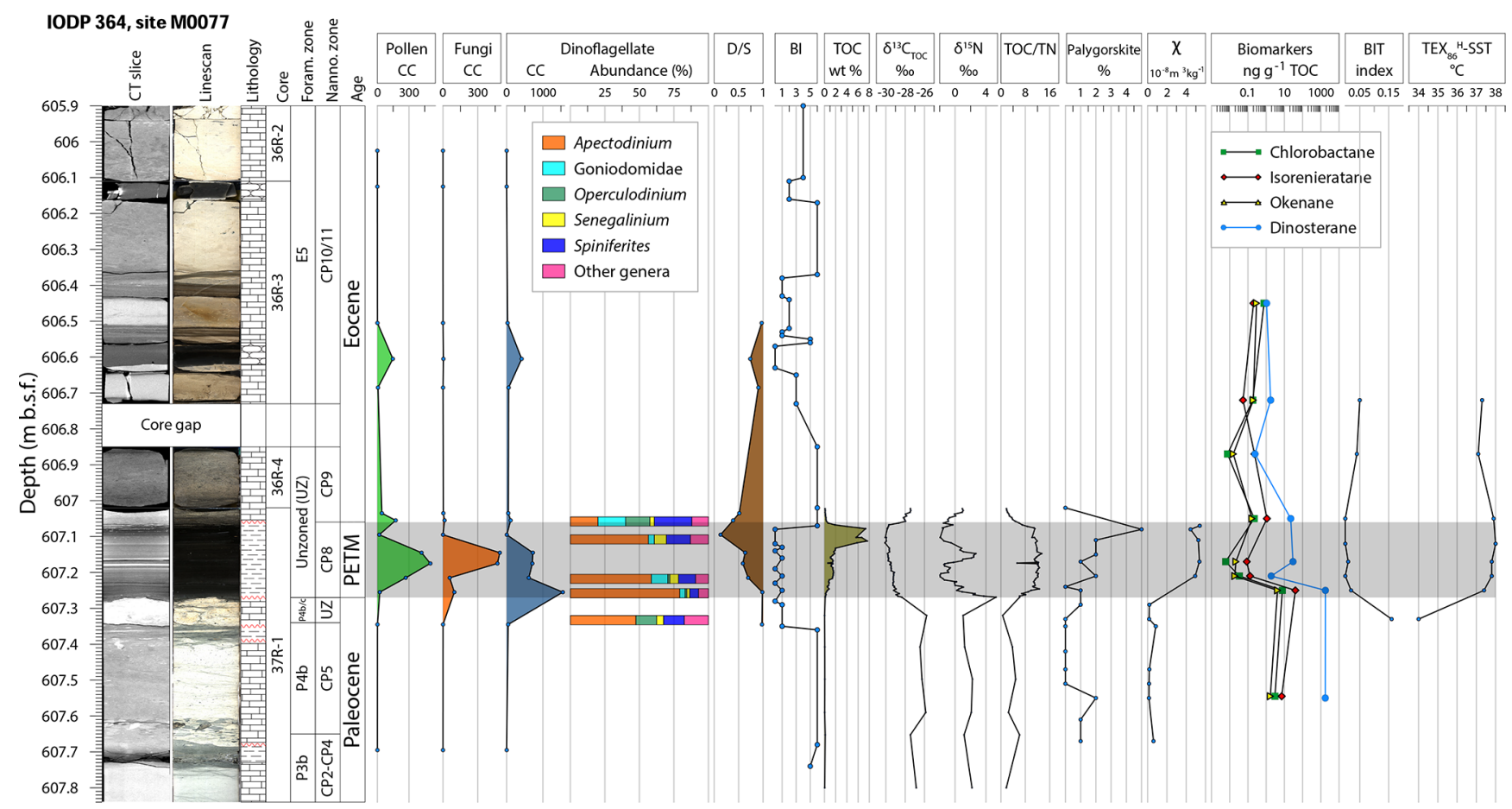

Figure 2. Stratigraphic column of Site M0077. Palynological concentrations (CC) are given as specimens per gram. $\delta^{15} \mathrm{~N}$ is reported relative to atmospheric $\mathrm{N}_{2}$, and $\delta^{13} \mathrm{C}_{\mathrm{TOC}}$ is reported relative to VPDB. BI: bioturbation index (Taylor and Goldring, 1993), CT: computed tomography, D / S: dinoflagellate cyst to pollen and plant spore ratio (Warny et al., 2003), TOC / TN: total organic carbon / total nitrogen, TOC: total organic carbon, $\chi$ : magnetic susceptibility. Lithological symbols: rectangular blocks - limestone, dashes - shale and claystone, obround ovals - chert, red wavy lines - unconformities.

calcispheres. Laminae are commonly defined at their base by quartz and muscovite silt and grade upward into clay and organic-rich shale. The uppermost PETM shale is bioturbated, with burrows infilled with material from the overlying carbonate packstone. The interval directly overlying the PETM (607.06-606.85 mb.s.f.) also contains abundant reworked material, including several pebble-sized clasts of limestone that appear to contain Cretaceous foraminifera. Above the core gap, Cores 36R-3 and 36R-2 are composed of a pale massive packstone with two black chert layers at 606.62-606.56 and 606.16-606.11 mb.s.f. (Fig. 2).

Bioturbation is absent to minimal in the PETM, with rare Chondrites ichnofossils, except at the top of the interval (607.11-607.06 mb.s.f.) where Planolites burrows are observed, infilled with sediment from the overlying packstone. The clay mineral assemblages are dominated by R0 random illite-smectite mixed layers (up to $90 \%$ ) and also contain traces of chlorite, illite, and palygorskite. The latter is rare in the upper Paleocene and increases in abundance through the PETM, reaching a peak of $5 \%$ relative abundance at $607.08 \mathrm{mb}$ b.s.f. The PETM interval is characterized by a marked increase in magnetic susceptibility $(\chi)$, anhysteretic remanent magnetization (ARM), and isothermal remanent magnetization (IRM). The average values increase by a factor of 15.7, 5.8, and 12.4 for $\chi$, ARM, and IRM, re- spectively, compared to the average values over the analyzed pre-PETM interval (607.67-607.27 mb.s.f.) (see the Supplement).

Total organic carbon (TOC) is low above and below the PETM (Fig. 2), with high concentrations (>6\% rock weight) in the upper PETM section. Total organic carbon / total nitrogen (TOC / TN) ratios (e.g., Meyers and Shaw, 1996) range from 0.6 to 6.8 in the upper Paleocene, with higher values averaging 10.7 in the PETM section. TOC / TN values in the post-PETM section range from 1.4 to 4.7. $\delta^{13} \mathrm{C}_{\mathrm{TOC}}$ (total organic carbon $\delta^{13} \mathrm{C}$ ) ranges from $-27.5 \%$ to $-25.8 \%$ in the upper Paleocene and is $-28.4 \%$ at the base of the PETM section, generally becoming more negative up-section through the PETM, with the most depleted value of $-30.1 \%$ in the upper PETM (607.12 mb.s.f.). Above 607.07 mb.s.f., $\delta^{13} \mathrm{C}_{\mathrm{TOC}}$ values become more positive, then stabilize at $-27.5 \%$ at $607.03 \mathrm{mb}$ b.s.f. $\delta^{15} \mathrm{~N}$ ranges from $1.0 \%$ to $3.7 \%$ in the upper Paleocene and is 5.3\%o at the base of the PETM section, with more depleted values through the PETM, reaching a minimum of $-2.0 \%$ at $607.21 \mathrm{mb}$.s.f. The PETM $\delta^{15} \mathrm{~N}$ record is marked by two negative excursions with values below $0 \%$, separated by a brief interval of positive $\delta^{15} \mathrm{~N}$ values between 607.17 and 607.13 mb.s.f. Above 607.10 mb.s.f., 
$\delta^{15} \mathrm{~N}$ values become more positive, with a value of $0.9 \%$ at 607.02 mb.s.f. (Fig. 2).

$\mathrm{TEX}_{86}^{\mathrm{H}}$-based SSTs and other biomarkers were difficult to retrieve in the late Paleocene due to low organic matter content (TOC values often $<0.1 \%$ ), but a single sample at $607.33 \mathrm{mb}$ b.s.f. yielded a TEX $\mathrm{T}_{6}^{\mathrm{H}}$-based SST of $34.0^{\circ} \mathrm{C}$. In the PETM interval, $\mathrm{TEX}_{86^{\mathrm{H}}}^{\mathrm{H}}$-based SSTs ranged 37.4$38.0^{\circ} \mathrm{C}$, averaging $37.8^{\circ} \mathrm{C}$. Just above the PETM section, at $607.05 \mathrm{~m}$ b.s.f., the $\mathrm{TEX}_{86^{\mathrm{H}}}^{\mathrm{H}}$-based SST was $37.9^{\circ} \mathrm{C}$, followed by a decrease in SSTs to 37.1 and $37.3^{\circ} \mathrm{C}$ at 606.87 and $606.72 \mathrm{mb}$.s.f., respectively (Fig. 2). To verify the applicability of the $\mathrm{TEX}_{86}$ proxy a series of complementary molecular indicators, including the BIT (branched and isoprenoid tetraether) index (Hopmans et al., 2004), MI (methane index), and $f_{\text {cren }}$ (relative abundance of the crenarchaeol regioisomer), were calculated, all of which passed the exclusion criteria as summarized in O'Brien et al. (2017). Green and purple sulfur bacteria biomarkers (chlorobactane, isorenieratane, and okenane) reach their highest concentrations near the bottom of the PETM section, with low concentrations through the rest of the event (Fig. 2).

Nannofossil abundances decrease through the PETM section and become rare in the post-PETM section. Foraminifera at Site M0077 are abundant in the upper Paleocene section but are absent to very rare in the PETM section, with evidence of reworking. Dinosteranes, biomarkers associated with dinoflagellates (e.g., Summons et al., 1987), have relatively high concentrations in the upper Paleocene and lower PETM section, with decreased abundance in the PETM and post-PETM sections. Organic-walled microfossils are absent to rare in the Paleocene. Dinoflagellate cyst concentrations peak at $607.26 \mathrm{mb}$.s.f., with a decreasing trend through the rest of the PETM (Fig. 2). Relative abundances of Apectodinium are highest at $607.26 \mathrm{mb}$.s.f. and decrease through the PETM, while the highest relative abundances of Goniodomidae are found just above the event. Fungal spore concentrations peak in the middle of the PETM section (Fig. 2), reaching concentrations much higher $\left(>400\right.$ specimens $^{-1}$ ) than any other samples, including samples with a higher overall palynomorph concentration and excellent preservation in the later Ypresian section near the top of the core (520.79-505.88 mb.s.f.), indicating the fungal spike is not a taphonomic artifact. The PETM fungal assemblage is dominated by Nigrospora types, which are common leaf endophytes on a variety of substrates, including soil, and are commonly airborne (Wang et al., 2017). The PETM pollen and plant spore assemblage is dominated by Malvacipollis (Euphorbiaceae), Ulmipollenites (Ulmaceae), Bohlensipollis (Eleagnaceae), and angiosperm pollen of unknown lower botanical affinity, with rare gymnosperm pollen and lower plant spores.

\section{Discussion}

\subsection{Stratigraphy and depositional environment}

As described earlier, the PETM section in the Site M0077 core is bracketed by unconformities and incomplete, with the onset and recovery missing, and only part of the PETM section is preserved. The fine-grained nature and lack of sedimentary structures indicating current deposition indicate that the PETM interval recovered was deposited in relatively deep, quiet water with sediments largely settling from suspension. The laminated black shale points toward low oxygen conditions. However, the trace fossil assemblage implies that anoxia and/or euxinia were likely intermittent. Water depths for Site M0077 during most of the Paleocene were on the order of 600-700 m (Lowery et al., 2018), but the facies immediately underlying and overlying the PETM interval contain numerous grains from shallow water environments, like larger benthic foraminifera and red algae, which indicate either relatively shallow water in the crater or extensive reworking from the crater margin. Assigning a water depth for the PETM interval is complicated by the complete lack of obviously in situ depth-sensitive benthic foraminifera that could provide such insight. However, the presence of deeperdwelling planktic foraminifera such as Subbotina spp. and Globanomalina pseudomenardii, which occupied a thermocline habitat (e.g., Aze et al., 2011), indicates that the water was at least deep enough for the establishment of stratification. The PETM is globally characterized by an eustatic sea level rise (Sluijs et al., 2008), so water depths were likely somewhat deeper during the PETM than during the times when the units above and below were deposited. The reworking observed in PETM age sediments in the Yaxcopoil1 core (Whalen et al., 2013) suggests that reworking in the Chicxulub crater was common during the PETM, and the shallow water foraminifera observed in the PETM section at Site M0077 were likely reworked from the crater rim.

The PETM age of the shale interval at Site M0077 (607.27-607.06 mb.s.f.) has been confirmed by a negative carbon isotope excursion (CIE) and biostratigraphy. The earliest nannofossil PETM sample, at 607.25 mb.s.f., contains Discoaster salisburgensis var. anartios, a characteristic PETM excursion taxon (e.g., Bralower and Self-Trail, 2016). The global negative CIE is also observed at Site M0077 (Fig. 2). In complete records of the PETM, the peak of the negative CIE and highest temperatures are observed within the first $\sim 20 \mathrm{kyr}$ of the event, followed by a gradual recovery to more positive $\delta^{13} \mathrm{C}_{\mathrm{TOC}}$ values and lower SSTs (e.g., Hollis et al., 2019). However, at Site M0077, the most depleted $\delta^{13} \mathrm{C}_{\mathrm{TOC}}$ values are found in the upper part of the interval. The onset and peak of the PETM CIE are thus missing due to erosion or non-deposition. The abrupt shift to more positive $\delta^{13} \mathrm{C}_{\text {TOC }}$ values at $607.06 \mathrm{mb}$.s.f. suggests that the later PETM section and immediate recovery are also missing, with another unconformity at the top of the PETM section. The 
trend towards more negative $\delta^{13} \mathrm{C}_{\mathrm{TOC}}$ values in the PETM can be explained as the result of an increasing contribution of terrestrial organic matter. This explanation is consistent with the palynological D / S ratio, which shows the highest relative abundance of terrestrial vs. marine palynomorphs at approximately the same depth as the most negative $\delta^{13} \mathrm{C}_{\mathrm{TOC}}$ values (Fig. 2). Increasing TOC / TN ratios are also consistent with a higher input of terrestrial organic matter through the PETM (e.g., Burdige, 2006). Lithologically, the PETM section is clearly distinguished from the Paleocene section by an abrupt switch from carbonate to siliciclastic clay deposition and an abrupt increase in detrital input, as indicated by increased magnetic parameters.

\subsection{PETM environmental change}

SSTs were estimated using the relative abundance of thaumarchaeotal isoGDGTs. Here we used the TEX $\mathrm{H}_{86}^{\mathrm{H}}$ SST calibration of Kim et al. (2010) developed for the determination of SSTs in (sub)tropical oceans and low-latitude settings. The uncertainties associated with $\mathrm{TEX}_{86}$ estimates of SSTs exceeding the present-day SST maximum of 27$29^{\circ} \mathrm{C}$ have been addressed for Cretaceous (O'Brien et al., 2017) and Paleogene (Frieling et al., 2017) strata. The conclusion is that during hyperthermals $\mathrm{TEX}_{86}^{\mathrm{H}}$ delivers reliable SST reconstructions, with an upper calibration limit occurring at $38.6^{\circ} \mathrm{C}$ (O'Brien et al., 2017). The $\mathrm{TEX}_{86}$ ratios in the PETM section approach unity (0.96-0.98), nearing the theoretical upper limit for temperature reconstruction using this proxy. BAYSPAR (Tierney and Tingley, 2014) and linear (Schouten et al., 2007) TEX 86 calibrations yield extremely high PETM SSTs in excess of $44^{\circ} \mathrm{C}$, which is above the heat tolerance for most dinoflagellates, foraminifera, and other eukaryotic plankton. GDGT abundance data are provided in the Supplement so that alternative and possible future TEX $_{86}$ calibrations can be applied to the dataset. In previous studies potential impacts on the $\mathrm{TEX}_{86}$ proxy have been identified and a series of validation criteria developed as summarized in O'Brien et al. (2017). The application of these validation proxies identified all samples as fulfilling the exclusion criteria for the use of the $\mathrm{TEX}_{86}^{\mathrm{H}}$ paleothermometer. The thermal maturity as determined by the side chain isomerization of the $\mathrm{C}_{29} \alpha \alpha \alpha$ steranes [20S / $\left.(20 \mathrm{~S}+20 \mathrm{R})\right]$ and $\mathrm{C}_{31} \alpha \beta$ hopanes $[20 \mathrm{~S} /(20 \mathrm{~S}+20 \mathrm{R})]$ is 0.13 and 0.34 , respectively (see the Supplement), which is indicative of a low maturity, equivalent to a vitrinite reflectivity of $0.30 \%-0.35 \%$. This is supported by Rock-Eval $T_{\max }$ values averaging $428^{\circ} \mathrm{C}$. A maturity impact on the GDGT data is thus considered to be minimal and affecting all samples to an equal extent. Preservation of immature biomarkers is further supported by the presence of thermally labile aromatic carotenoids.

$\mathrm{TEX}_{86}^{\mathrm{H}}$-based SSTs increased by $\sim 4{ }^{\circ} \mathrm{C}$ between the late Paleocene and PETM (Fig. 2), with average PETM SSTs of $37.8^{\circ} \mathrm{C}$ determined here, similar to values observed in the eastern equatorial Atlantic (Frieling et al., 2018) and the
Dahomey Basin, western Africa (Frieling et al., 2017), and $\sim 3^{\circ} \mathrm{C}$ higher than those observed in the Harrell Core (Sluijs et al., 2014) on the northern Gulf of Mexico margin and Wilson Lake core (Zachos et al., 2006) on the mid-Atlantic North American margin. Jaramillo et al. (2010) estimated late Paleocene SSTs of $28-31^{\circ} \mathrm{C}$ and early Eocene SSTs of $31-34^{\circ} \mathrm{C}$ from Colombia using $\mathrm{TEX}_{86}$ measurements, although no PETM age TEX $_{86}$ measurements were available. Frieling et al. (2017), investigating a tropical marine PETM record from Nigeria, estimated latest Paleocene SSTs of 32$34{ }^{\circ} \mathrm{C}$, with average PETM SSTs of $\sim 36^{\circ} \mathrm{C}$. The temperature increase from the late Paleocene to PETM section at Site M0077 is consistent with estimates of a $4-5^{\circ} \mathrm{C}$ global mean surface temperature anomaly for the PETM (Dunkley Jones et al., 2013). SSTs decrease to 37.1 and $37.3^{\circ} \mathrm{C}$ in the postPETM section at 606.87 and 606.72 mb.s.f., respectively.

Several lines of evidence indicate increased terrestrial input during the PETM, including increased concentrations of terrestrial palynomorphs, increased D / S and TOC / TN ratios, and an increase in detrital ferromagnetic minerals. Theoretically, this increase in terrestrial input could be the result of a relative sea level fall, but this would not be consistent with an interpreted PETM sea level rise in the Gulf of Mexico and globally (Sluijs et al., 2014). Instead, the increase in terrestrial input is interpreted to result from an intensified hydrological cycle during the PETM, as noted in other studies (e.g., Crouch et al., 2003; Bowen et al., 2004; Schmitz and Pujalte, 2007; Handley et al., 2012). The exceptionally high abundance of fungal spores in the PETM section suggests that increased humidity and terrestrial weathering resulted in greater detrital and nutrient input to Site M0077. BIT index values, which have been used as a proxy for terrestrial organic matter in sediments (Hopmans et al., 2004; Weijers et al., 2006), are higher in the late Paleocene than in the PETM section (Fig. 2). Low BIT values in samples from the PETM section may indicate a source of terrestrial organic matter lean in soil microbial matter (Huguet et al., 2007; Schouten et al., 2013), possibly from low-lying carbonate terrain to the south (Fig. 1) and/or increased productivity of Thaumarchaeota.

The relative abundance of the clay mineral palygorskite increases through the PETM section. Higher abundances of palygorskite in other PETM sediments have been interpreted as evidence for increased aridity (Carmichael et al., 2017), as palygorskite commonly forms in coastal marine environments in which continental alkaline waters are concentrated by evaporation (Bolle and Adatte, 2001). At Site M0077, the palygorskite may have originally formed in hypersaline lagoonal environments similar to other Eocene-Oligocene palygorskite deposits in the Yucatán Peninsula (de Pablo Galán, 1996). The increase in the relative abundance of palygorskite through the PETM section may therefore be the result of increased fluvial transport of sediments to Site M0077 from lagoonal environments to the south rather than the result of increased aridity. 
The near absence of bioturbation in the PETM section, with preserved sedimentary lamination and high TOC, is consistent with bottom water anoxia through much of the PETM, and sulfur bacteria biomarkers are indicative of photic zone euxinia (e.g., Summons and Powell, 1987; Grice et al., 2005; Sluijs et al., 2014) in the earlier PETM record. Depleted $\delta^{15} \mathrm{~N}$ values similar to those observed during ocean anoxic events (e.g., Jenkyns, 2010) can be explained by upwelling of ammonium from anoxic deep waters during periods of high nutrient availability (e.g., Higgins et al., 2012) or increased cyanobacterial $\mathrm{N}_{2}$ fixation (e.g., Bauersachs et al., 2009). The transient positive $\delta^{15} \mathrm{~N}$ excursion in the middle of the PETM section at Site M0077 (Fig. 2) is similar to the $\delta^{15} \mathrm{~N}$ PETM record of Junium et al. (2018) from the northern Peri-Tethys seaway, with depleted $\delta^{15} \mathrm{~N}$ in the top and bottom of the PETM section separated by an interval of more enriched $\delta^{15} \mathrm{~N}$, which they interpreted to result from a more oxic, less stratified water column, possibly due to reduced freshwater influx.

\subsection{Implications for life and climate}

In the Paleocene interval at Site M0077, carbonate deposition dominates and palynomorphs are nearly absent, probably due to poor preservation of organic material (Lowery et al., 2018, 2020). Low values of TOC / TN $(<4)$ observed in the Paleocene section are also an indication of degradation of organic matter, the breakdown of nitrogenous compounds to ammonia, and subsequent $\mathrm{CO}_{2}$ release via oxidation (Müller, 1977; Meyers and Shaw, 1996). The late Paleocene palynological samples in the carbonate hardground represent the oldest dinoflagellate assemblages observed in abundances sufficient for paleoecological interpretation. Dinoflagellate cyst and dinosterane concentrations peak in the early PETM interval, then decrease through the rest of the recovered PETM, suggesting that the extreme warmth during the PETM resulted in heat-stressed plankton within the Chicxulub impact crater, similar to the eastern equatorial Atlantic (Frieling et al., 2018). Dinoflagellate assemblages record a peak in Apectodinium relative abundance in the lowermost PETM sample and then a decrease in abundance through the rest of the PETM. Increases in the relative abundance of Goniodomidae through the PETM likely indicate an intensification in salinity stratification (e.g., Frieling and Sluijs, 2018). In the later Ypresian dinoflagellate assemblages, Spiniferites becomes the dominant genus and Apectodinium is nearly absent. The PETM nannoplankton assemblage contains malformed Discoaster specimens, which may represent ecophenotypes that migrated to a deep photic zone refuge to escape inhospitable SSTs and became malformed due to increased organic matter remineralization and calcite undersaturation (Bralower and Self-Trail, 2016).
A notable acme of fungal spores occurs in the middle part of the PETM. This acme is dominated by aff. Nigrospora sp., possibly suggesting increased moisture levels, which resulted in increased fungal decomposition of herbaceous and woody substrates on land (Dighton, 2016; Wang et al., 2017) as well as increased terrestrial runoff. The release of soluble nutrients by saprotrophic fungi such as Nigrospora may have significantly contributed to increased marine productivity at Site M0077 during the PETM. However, Nigrospora can also be transported by dust storms (Wang et al., 2017) and lives in marine environments (Dighton and White, 2017), including deep-sea sediments (Singh et al., 2012) and microbial mats in anoxic, hypersaline coastal environments (Cantrell et al., 2006).

The PETM pollen and plant spore assemblage is broadly similar to later Ypresian assemblages observed higher in the core, with angiosperm pollen dominant, particularly reticulate tricolpate-tricolporate pollen of unknown lower botanical affinity (e.g., Fraxinoipollenites spp. and Retitricolporites spp.), Malvacipollis spp. (Euphorbiaceae), Psilatricolpites sp. A, and Ulmipollenites krempii (Ulmaceae). The PETM pollen and plant spore assemblage is distinguished from the later Ypresian assemblages by higher relative abundances of Boehlensipollis sp. A (Elaeagnaceae), Malvacipollis spp., and Scabratricolpites sp. A (Smith et al., 2020a, b), suggesting that these may be thermophilic taxa. Lower plant spores and gymnosperm pollen are rare in both the PETM and later Ypresian assemblages. The main pollen source area is interpreted as a lowland tropical forest and shrubland (Smith et al., 2020a, b). Pollen with affinity to the Pinopsida and Ulmaceae may represent a contribution from more upland pollen source areas based on their modern distributions in Mexico and Central America. High concentrations of pollen in two PETM samples argue for a proximal pollen source area from low-elevation carbonate terrain in the $\mathrm{Yu}$ catán Peninsula, consistent with modeled prevailing surface currents and summer wind fields from the south (Fig. 2) (Winguth et al., 2010). Globally, plant floras indicate shifts in ranges and relative abundances with low rates of extinction (Wing and Currano, 2013). These shifts are broadly indicative of warming during the PETM. Although plant assemblages in midlatitude continental interiors suggest drying during the PETM (e.g., Wing et al., 2005), PETM floral records from tropical South America (Jaramillo et al., 2010) and India (e.g., Prasad et al., 2018) suggest high levels of precipitation, whereas in tropical East Africa (Handley et al., 2012) evidence suggests a decrease in overall humidity but an increase in the intensity of precipitation events. The proxy data from Site M0077 indicate that increased temperature and humidity in the Yucatán Peninsula region during the PETM resulted in increased terrestrial input. 


\section{Conclusions}

The PETM in the Chicxulub impact crater was a time of extremely high SSTs $\left(\sim 37.8^{\circ} \mathrm{C}\right)$, increased terrestrial input, high surface productivity, water column stratification, and bottom water hypoxia-anoxia, with evidence for photic zone euxinia in the bottom of the section. The observed increase in terrestrial input is likely the result of increased weathering and fluvial discharge due to moist, hyperthermal conditions. This explanation is consistent with global evidence of sea level rise during the PETM. Seafloor anoxia decimated the marine benthos during the PETM, while high SSTs caused heat stress in the dinoflagellate and likely other phytoplankton assemblages. In contrast, the pollen and spore assemblage indicates the presence of a proximal humid landmass with a diverse tropical shrubby forest, which produced relatively high abundances of Euphorbiaceae pollen. These results, in combination with previously described tropical PETM floral assemblages (Jaramillo et al., 2010; Srivastava and Prasad, 2015; Prasad et al., 2018), demonstrate that tropical vegetation was highly resilient to hyperthermal conditions.

Data availability. All data and supplementary methods are included in the Supplement.

Supplement. The supplement related to this article is available online at: https://doi.org/10.5194/cp-16-1889-2020-supplement.

Team list. IODP-ICDP Expedition 364 Scientists: Joanna Morgan (Department of Earth Science and Engineering, Imperial College London, UK), Sean P. S. Gulick (Department of Geological Sciences, Jackson School of Geosciences, University of Texas at Austin, Austin, TX 78712, USA; Institute for Geophysics, Jackson School of Geosciences, University of Texas at Austin, Austin, TX 78712, USA), Claire Mellett (British Geological Survey, The Lyell Center, UK), Johanna Lofi (CNRS, Aix-Marseille Univ, IRD, Coll France; INRAE, CEREGE, Aix-en-Provence, France), Elise Chenot (GeoRessources, Université de Lorraine, CNRS, France), Gail Christeson (Institute for Geophysics, Jackson School of Geosciences, University of Texas at Austin, Austin, TX 78712, USA), Phillippe Clayes (Analytical, Environmental, and GeoChemistry, Vrije Universiteit Brussel, Belgium), Charles Cockell (Center for Astrobiology, School of Physics and Astronomy, University of Edinburgh, UK), Marco Coolen (Department of Chemistry, Western Australian Organic and Isotope Geochemistry Centre (WA-OIGC), Curtin University, Australia), Ludovic Ferrière (Natural History Museum, Austria), Catalina Gebhardt (Alfred Wegener Institute Helmholtz Centre of Polar and Marine Research, Germany), Kazuhisa Goto (International Research Institute of Disaster Science, Tohoku University, Japan), Heather Jones (Department of Geosciences, Pennsylvania State University, University Park, PA 16801, USA), David Kring (Lunar and Planetary Institute, Houston, TX 77058, USA), Christopher Lowery (Department of Geolog- ical Sciences, Jackson School of Geosciences, University of Texas at Austin, TX 78712, USA), Rubén Ocampo-Torres (Groupe de Physico-Chimie de l'Atmosphère, L'Institut de chimie et procédés pour l'énergie, l'environnement et la santé (ICPEES), France), Ligia Perez-Cruz (Instituto de Geofísica, Universidad Nacional Autónoma De México, Mexico), Annemarie E. Pickersgill (School of Geographical and Earth Sciences, University of Glasgow, UK), Michael Poelchau (Department of Geology, University of Freiburg, Germany), Auriol Rae (Department of Earth Science and Engineering, Imperial College London, UK), Cornelia Rasmussen (Institute for Geophysics, Jackson School of Geosciences, University of Texas at Austin, USA), Mario Rebolledo-Vieyra (Unidad de Ciencias del Agua, Centro de Investigación Científica de Yucatán, A.C., Mexico), Ulrich Riller (Institut für Geologie, Universität Hamburg, Germany), Honami Sato (Japan Agency for MarineEarth Science and Technology, Japan), Jan Smit (Faculty of Earth and Life Sciences FALW, Vrije Universiteit Amsterdam, Netherlands), Sonia Tikoo (Earth and Planetary Sciences, Rutgers University, New Brunswick, NJ 08854, USA), Naotaka Tomioka (Kochi Institute for Core Sample Research, Japan Agency for MarineEarth Science and Technology, Japan), Michael Whalen (Department of Geosciences, University of Alaska Fairbanks, Fairbanks, AK 99775, USA), Axel Wittmann (LeRoy Eyring Center for Solid State Science, Arizona State University, AZ 85281, USA), Kosei Yamaguchi (Department of Chemistry, Toho University, Japan), Long Xiao (School of Earth Sciences, Planetary Science Institute, China University of Geosciences (Wuhan), China), William Zylberman (CNRS, L'Institut de recherche pour le développement, Coll France, Aix Marseille University, France).

Author contributions. VS led the writing and organization of the paper. VS, SW, NBNO, and JMKO'K analyzed the terrestrial palynology. JV analyzed the dinoflagellate assemblages. KG, BS, ThB, and LS provided biomarker data and interpretation. MTW provided carbon and nitrogen isotopes and sedimentological evaluation of the core. KO'M provided additional isotope and geochemical data. IA, JAA, and CML researched the foraminiferal assemblages. EC provided clay mineralogy data. HJ provided nannofossil data. FJRT provided ichnological data. JG and FD provided magnetic data. SPSG, TiB, JL, JM, and other co-authors assisted with conceptualization and writing of the paper.

Competing interests. The authors declare that they have no conflict of interest.

Acknowledgements. This research used samples and data provided by the International Ocean Discovery Program (IODP). Thanks to Roger E. Summons and Xingqian Cui (MIT, US) for MRM analyses. This is University of Texas Institute for Geophysics contribution no. 3676 and Center for Planetary Systems Habitability contribution no. 0013 .

Financial support. This research has been supported by the CENEX (Center for Excellence in Palynology) Endowed Chair Fund, a scholarship from Louisiana State University, a 2018 
James M. and Thomas J. M. Schopf Award Student Research Grant from the Paleontological Society, an ARC-Discovery grant (DP180100982) from the Australian Research Council (ARC), a postgraduate award from Curtin University, IODP-France, the Research Foundation 100 Flanders (FWO grant 12Z6618N), NERC grant NE/P005217/1, and National Science Foundation OCE grants 14-50528, 1737199, 1736951, and 1737351.

Review statement. This paper was edited by Alberto Reyes and reviewed by C. Jaramillo and Kate Littler.

\section{References}

Aze, T., Ezard, T. H., Purvis, A., Coxall, H. K., Stewart, D. R., Wade, B. S., and Pearson, P. N.: A phylogeny of Cenozoic macroperforate planktonic foraminifera from fossil data, Biol. Rev., 86, 900-927, https://doi.org/10.1111/j.1469185X.2011.00178.x, 2011.

Bauersachs, T., Schouten, S., Compaoré, J., Wollenzien, U., Stal, L. J., and Sinninghe Damsté, J. S.: Nitrogen isotopic fractionation associated with growth on dinitrogen gas and nitrate by cyanobacteria, Limnol. Oceanogr., 54, 1403-1411, https://doi.org/10.4319/lo.2009.54.4.1403, 2009.

Bolle, M.-P. and Adatte, T.: Palaeocene-early Eocene climatic evolution in the Tethyan realm: clay mineral evidence, Clay Miner., 36, 249-261, 2001.

Bowen, G. J., Beerling, D. J., Koch, P. L., Zachos, J. C., and Quattlebaum, T.: A humid climate state during the Palaeocene/Eocene thermal maximum, Nature, 432, 495-499, https://doi.org/10.1038/nature03115, 2004.

Bralower, T. J. and Self-Trail, J. M.: Nannoplankton malformation during the Paleocene-Eocene Thermal Maximum and its paleoecological and paleoceanographic significance, Paleoceanography, 31, 1423-1439, https://doi.org/10.1002/2016PA002980, 2016.

Burdige, D. J.: Geochemistry of marine sediments, Princeton University Press, Princeton, NJ, 2006.

Carmichael, M. J., Inglis, G. N., Badger, M. P., Naafs, B. D. A., Behrooz, L., Remmelzwaal, S., Monteiro, F. M., Rohrssen, M., Farnsworth, A., and Buss, H. L.: Hydrological and associated biogeochemical consequences of rapid global warming during the Paleocene-Eocene Thermal Maximum, Global Planet. Change, 157, 114-138, https://doi.org/10.1016/j.gloplacha.2017.07.014, 2017.

Cantrell, S. A., Casillas-Martinez, L., and Molina, M.: Characterization of fungi from hypersaline environments of solar salterns using morphological and molecular techniques, Mycol. Res., 110, 962-970, https://doi.org/10.1016/j.mycres.2006.06.005, 2006.

Crouch, E. M., Dickens, G. R., Brinkhuis, H., Aubry, M.-P., Hollis, C. J., Rogers, K. M., and Visscher, H.: The Apectodinium acme and terrestrial discharge during the Paleocene-Eocene thermal maximum: new palynological, geochemical and calcareous nannoplankton observations at Tawanui, New Zealand, Palaeogeogr. Palaeocl., 194, 387-403, https://doi.org/10.1016/S00310182(03)00334-1, 2003. de Pablo Galán, L.: Palygorskite in eocene-oligocene lagoonal environment, Yucatan, Mexico, Rev. Mex. Cienc. Geol., 13, 94-103, 1996.

Dickens, G. R., Castillo, M. M., and Walker, J. C.: A blast of gas in the latest Paleocene: Simulating first-order effects of massive dissociation of oceanic methane hydrate, Geology, 25, 259-262, https://doi.org/10.1130/00917613(1997)025<0259:ABOGIT>2.3.CO;2, 1997.

Dickson, A. J., Rees-Owen, R. L., März, C., Coe, A. L., Cohen, A. S., Pancost, R. D., Taylor, K., and Shcherbinina, E.: The spread of marine anoxia on the northern Tethys margin during the Paleocene-Eocene Thermal Maximum, Paleoceanography, 29, 471-488, https://doi.org/10.1002/2014PA002629, 2014.

Dighton, J.: Fungi in ecosystem processes, 2nd edn., CRC Press, Boca Raton, FL, 2016.

Dighton, J. and White, J. F.: The fungal community: its organization and role in the ecosystem, 4th edn., CRC press, Boca Raton, FL, 2017.

Dunkley Jones, T., Lunt, D. J., Schmidt, D. N., Ridgwell, A., Sluijs, A., Valdes, P. J., and Maslin, M.: Climate model and proxy data constraints on ocean warming across the PaleoceneEocene Thermal Maximum, Earth-Sci. Rev., 125, 123-145, https://doi.org/10.1016/j.earscirev.2013.07.004, 2013.

Frieling, J. and Sluijs, A.: Towards quantitative environmental reconstructions from ancient non-analogue microfossil assemblages: Ecological preferences of PaleoceneEocene dinoflagellates, Earth-Sci. Rev., 185, 956-973, https://doi.org/10.1016/j.earscirev.2018.08.014, 2018.

Frieling, J., Gebhardt, H., Huber, M., Adekeye, O. A., Akande, S. O., Reichart, G.-J., Middelburg, J. J., Schouten, S., and Sluijs, A.: Extreme warmth and heat-stressed plankton in the tropics during the Paleocene-Eocene Thermal Maximum, Sci. Adv., 3, e1600891, https://doi.org/10.1126/sciadv.1600891, 2017.

Frieling, J., Reichart, G.-J., Middelburg, J. J., Röhl, U., Westerhold, T., Bohaty, S. M., and Sluijs, A.: Tropical Atlantic climate and ecosystem regime shifts during the Paleocene-Eocene Thermal Maximum, Clim. Past, 14, 39-55, https://doi.org/10.5194/cp-1439-2018, 2018.

Gingerich, P. D.: Environment and evolution through the Paleocene-Eocene thermal maximum, Trends Ecol. Evol., 21, 246-253, https://doi.org/10.1016/j.tree.2006.03.006, 2006.

Gradstein, F. M., Ogg, J. G., Schmitz, M., and Ogg, G.: The Geologic Time Scale 2012, Elsevier, Amsterdam, the Netherlands, 2012.

Grice, K., Cao, C., Love, G. D., Böttcher, M. E., Twitchett, R. J., Grosjean, E., Summons, R. E., Turgeon, S. C., Dunning, W., and Jin, Y.: Photic zone euxinia during the Permian-Triassic superanoxic event, Science, 307, 706-709, https://doi.org/10.1126/science.1104323, 2005.

Gulick, S. P., Barton, P. J., Christeson, G. L., Morgan, J. V., McDonald, M., Mendoza-Cervantes, K., Pearson, Z. F., Surendra, A., Urrutia-Fucugauchi, J., and Vermeesch, P. M.: Importance of pre-impact crustal structure for the asymmetry of the Chicxulub impact crater, Nat. Geosci., 1, 131-135, https://doi.org/10.1038/ngeo103, 2008.

Handley, L., O'Halloran, A., Pearson, P. N., Hawkins, E., Nicholas, C. J., Schouten, S., McMillan, I. K., and Pancost, R. D.: Changes in the hydrological cycle in trop- 
ical East Africa during the Paleocene-Eocene Thermal Maximum, Palaeogeogr. Palaeocl., 329, 10-21, https://doi.org/10.1016/j.palaeo.2012.02.002, 2012.

Higgins, M. B., Robinson, R. S., Husson, J. M., Carter, S. J., and Pearson, A.: Dominant eukaryotic export production during ocean anoxic events reflects the importance of recycled NH4+, P. Natl. Acad. Sci. USA, 109, 2269-2274, https://doi.org/10.1073/pnas.1104313109, 2012.

Hollis, C. J., Dunkley Jones, T., Anagnostou, E., Bijl, P. K., Cramwinckel, M. J., Cui, Y., Dickens, G. R., Edgar, K. M., Eley, Y., Evans, D., Foster, G. L., Frieling, J., Inglis, G. N., Kennedy, E. M., Kozdon, R., Lauretano, V., Lear, C. H., Littler, K., Lourens, L., Meckler, A. N., Naafs, B. D. A., Pälike, H., Pancost, R. D., Pearson, P. N., Röhl, U., Royer, D. L., Salzmann, U., Schubert, B. A., Seebeck, H., Sluijs, A., Speijer, R. P., Stassen, P., Tierney, J., Tripati, A., Wade, B., Westerhold, T., Witkowski, C., Zachos, J. C., Zhang, Y. G., Huber, M., and Lunt, D. J.: The DeepMIP contribution to PMIP4: methodologies for selection, compilation and analysis of latest Paleocene and early Eocene climate proxy data, incorporating version 0.1 of the DeepMIP database, Geosci. Model Dev., 12, 3149-3206, https://doi.org/10.5194/gmd-12-3149-2019, 2019.

Hopmans, E. C., Weijers, J. W., Schefuß, E., Herfort, L., Sinninghe Damsté, J. S., and Schouten, S.: A novel proxy for terrestrial organic matter in sediments based on branched and isoprenoid tetraether lipids, Earth Planet. Sc. Lett., 224, 107-116, https://doi.org/10.1016/j.epsl.2004.05.012, 2004.

Huguet, C., Smittenberg, R. H., Boer, W., Sinninghe Damsté, J. S., and Schouten, S.: Twentieth century proxy records of temperature and soil organic matter input in the Drammensfjord, southern Norway, Org. Geochem., 38, 1838-1849, https://doi.org/10.1016/j.orggeochem.2007.06.015, 2007.

Jaramillo, C., Ochoa, D., Contreras, L., Pagani, M., CarvajalOrtiz, H., Pratt, L. M., Krishnan, S., Cardona, A., Romero, M., and Quiroz, L.: Effects of rapid global warming at the PaleoceneEocene boundary on neotropical vegetation, Science, 330, 957961, https://doi.org/10.1126/science.1193833, 2010.

Jenkyns, H. C.: Geochemistry of oceanic anoxic events, Geochem. Geophy., Geosy., 11, 1-30, https://doi.org/10.1029/2009GC002788, 2010.

Junium, C. K., Dickson, A. J., and Uveges, B. T.: Perturbation to the nitrogen cycle during rapid Early Eocene global warming, Nat. Commun., 9, 3186, https://doi.org/10.1038/s41467-018-05486w, 2018.

Kim, J.-H., Van der Meer, J., Schouten, S., Helmke, P., Willmott, V., Sangiorgi, F., Koç, N., Hopmans, E. C., and Sinninghe Damsté, J. S.: New indices and calibrations derived from the distribution of crenarchaeal isoprenoid tetraether lipids: Implications for past sea surface temperature reconstructions, Geochim. Cosmochim. Ac., 74, 4639-4654, https://doi.org/10.1016/j.gca.2010.05.027, 2010.

Lefticariu, M., Perry, E. C., Ward, W. C., and Lefticariu, L.: PostChicxulub depositional and diagenetic history of the northwestern Yucatan Peninsula, Mexico, Sediment. Geol., 183, 51-69, https://doi.org/10.1016/j.sedgeo.2005.09.008, 2006.

Lowery, C. M., Bralower, T. J., Owens, J. D., Rodríguez-Tovar, F. J., Jones, H., Smit, J., Whalen, M. T., Claeys, P., Farley, K., and Gulick, S. P.: Rapid recovery of life at ground zero of the end-Cretaceous mass extinction, Nature, 558, 288-291, https://doi.org/10.1038/s41586-018-0163-6, 2018.

Lowery, C., Jones, H. L., Bralower, T. J., Perez Cruz, L. P., Gebhardt, C., Whalen, M. T., Chenot, E., Smit, J., Phillips, M. P., Choumiline, K., Arenillas, I., Arz, J., Garcia, F., Ferrand, M., and Choumiline, and Gulick, S. P.: Early Paleocene Paleoceanography and Export Productivity in the Chicxulub Crater, EarthArXiv (preprint), available at: https://eartharxiv.org/j8fsd/, last access: 20 July 2020.

McInerney, F. A. and Wing, S. L.: The Paleocene-Eocene Thermal Maximum: A perturbation of carbon cycle, climate, and biosphere with implications for the future, Annu. Rev. Earth Pl. Sc., 39, 489-516, https://doi.org/10.1146/annurev-earth-040610133431, 2011.

Meyers, P. A. and Shaw, T. J.: Organic matter accumulation, sulfate reduction, and methanogenesis in Pliocene-Pleistocene turbidites on the Iberia Abyssal Plain, in: Proceedings of the Ocean Drilling Program, Scientific Results, Ocean Drilling Program, College Station, TX, USA, vol. 149, 705-712, 1996.

Morgan, J., Warner, M., Brittan, J., Buffler, R., Camargo, A., Christeson, G., Denton, P., Hildebrand, A., Hobbs, R., Macintyre, H., Mackenzie, G., Maguire, P., Marin, L., Nakamura, Y., Pilkington, M., Sharpton, V., Snyder, D., Suarez, G., and Trejo, A.: Size and morphology of the Chicxulub impact crater, Nature, 390, 472-476, https://doi.org/10.1038/37291, 1997.

Morgan, J. V., Gulick, S. P. S., Mellet, C. L., Green, S. L., and the Expedition 364 Scientists: Chicxulub: Drilling the K-Pg Impact Crater, in: Proceedings of the International Ocean Discovery Program, International Ocean Discovery Program, College Station, TX, USA, Vol. 364, 2017.

Müller, P. J.: CN ratios in Pacific deep-sea sediments: Effect of inorganic ammonium and organic nitrogen compounds sorbed by clays, Geochim. Cosmochim. Ac., 41, 765-776, https://doi.org/10.1016/0016-7037(77)90047-3, 1977.

O'Brien, C. L., Robinson, S. A., Pancost, R. D., Sinninghe Damsté, J. S., Schouten, S., Lunt, D. J., Alsenz, H., Bornemann, A., Bottini, C., Brassell, S. C., Farnsworth, A., Forster, A., Huber, B. T., Inglis, G. A., Jenkyns, H. C., Linnert, C., Littler, K., Markwick, P., McAnena, A., Mutterlose, J., Naafs, D. A., Püttmann, W., Sluijs, A., van Helmond, N. A. G. M., Vellekoop, J., Wagner, T., and Wrobel, N. E.: Cretaceous seasurface temperature evolution: Constraints from $\mathrm{TEX}_{86}$ and planktonic foraminiferal oxygen isotopes, Earth-Sci. Rev., 172, 224-247, https://doi.org/10.1016/j.earscirev.2017.07.012, 2017.

Prasad, V., Utescher, T., Sharma, A., Singh, I. B., Garg, R., Gogoi, B., Srivastava, J., Uddandam, P. R., and Joachimski, M. M.: Low-latitude vegetation and climate dynamics at the Paleocene-Eocene transition-A study based on multiple proxies from the Jathang section in northeastern India, Palaeogeogr. Palaeocl., 497, 139-156, https://doi.org/10.1016/j.palaeo.2018.02.013, 2018.

Schmitz, B. and Pujalte, V.: Abrupt increase in seasonal extreme precipitation at the Paleocene-Eocene boundary, Geology, 35, 215-218, https://doi.org/10.1130/G23261A.1, 2007.

Schouten, S., Hopmans, E. C., Schefuß, E., and Sinninghe Damsté, J. S.: Distributional variations in marine crenarchaeotal membrane lipids: a new tool for reconstructing ancient sea water temperatures?, Earth Planet. Sc. Lett., 204, 265-274, https://doi.org/10.1016/S0012-821X(02)00979-2, 2002. 
Schouten, S., Forster, A., Panoto, F. E., and Damsté, J. S. S.: Towards calibration of the TEX86 palaeothermometer for tropical sea surface temperatures in ancient greenhouse worlds, Org. Geochem., 38, 1537-1546, https://doi.org/10.1016/j.orggeochem.2007.05.014, 2007.

Schouten, S., Hopmans, E. C., and Sinninghe Damsté, J. S.: The organic geochemistry of glycerol dialkyl glycerol tetraether lipids: a review, Org. Geochem., 54, 19-61, https://doi.org/10.1016/j.orggeochem.2012.09.006, 2013.

Scotese, C. R. and Wright, N.: PALEOMAP paleodigital elevation models (PaleoDEMS) for the Phanerozoic, available at: https://www.earthbyte.org/ paleodem-resource-scotese-and-wright-2018 (last access: 15 February 2020), 2018.

Singh, P., Raghukumar, C., Meena, R. M., Verma, P., and Shouche, Y.: Fungal diversity in deep-sea sediments revealed by culture-dependent and culture-independent approaches, Fungal Ecol., 5, 543-553, https://doi.org/10.1016/j.funeco.2012.01.001, 2012.

Sluijs, A., Brinkhuis, H., Crouch, E. M., John, C. M., Handley, L., Munsterman, D., Bohaty, S. M., Zachos, J. C., Reichart, G.-J., and Schouten, S.: Eustatic variations during the Paleocene-Eocene greenhouse world, Paleoceanography, 23, 118, https://doi.org/10.1029/2008PA001615, 2008.

Sluijs, A., van Roij, L., Harrington, G. J., Schouten, S., Sessa, J. A., LeVay, L. J., Reichart, G.-J., and Slomp, C. P.: Warming, euxinia and sea level rise during the Paleocene-Eocene Thermal Maximum on the Gulf Coastal Plain: implications for ocean oxygenation and nutrient cycling, Clim. Past, 10, 1421-1439, https://doi.org/10.5194/cp-10-1421-2014, 2014.

Smith, V., Warny, S., Jarzen, D., Demchuk, T., Vajda, V., and The Expedition 364 Scientific Party: Palaeocene-Eocene miospores from the Chicxulub impact crater, Mexico. Part 1: spores and gymnosperm pollen, Palynology, 44, 473-487, https://doi.org/10.1080/01916122.2019.1630860, 2020a.

Smith, V., Warny, S., Jarzen, D., Demchuk, T., Vajda, V., and Gulick, S. P.: Paleocene-Eocene palynomorphs from the Chicxulub impact crater, Mexico. Part 2: angiosperm pollen, Palynology, 44, 489-519, https://doi.org/10.1080/01916122.2019.1705417, 2020b.

Srivastava, J. and Prasad, V.: Effect of global warming on diversity pattern in Nypa mangroves across PaleoceneEocene transition in the paleo-equatorial region of the Indian sub-continent, Palaeogeogr. Palaeocl., 429, 1-12, https://doi.org/10.1016/j.palaeo.2015.03.026, 2015.

Summons, R. E. and Powell, T. G.: Identification of aryl isoprenoids in source rocks and crude oils: biological markers for the green sulphur bacteria, Geochim. Cosmochim. Ac., 51, 557566, https://doi.org/10.1016/0016-7037(87)90069-X, 1987.

Summons, R. E., Volkman, J. K., and Boreham, C. J.: Dinosterane and other steroidal hydrocarbons of dinoflagellate origin in sediments and petroleum, Geochim. Cosmochim. Ac., 51, 30753082, https://doi.org/10.1016/0016-7037(87)90381-4, 1987.
Taylor, A. M. and Goldring, R.: Description and analysis of bioturbation and ichnofabric, J. Geol. Soc. London, 150, 141-148, https://doi.org/10.1144/gsjgs.150.1.0141, 1993.

Tierney, J. E. and Tingley, M. P.: A Bayesian, spatially-varying calibration model for the TEX 86 proxy, Geochim. Cosmochim. Ac., 127, 83-106, https://doi.org/10.1016/j.gca.2013.11.026, 2014.

Wang, M., Liu, F., Crous, P. W., and Cai, L.: Phylogenetic reassessment of Nigrospora: ubiquitous endophytes, plant and human pathogens, Persoonia, 39, 118-142, https://doi.org/10.3767/persoonia.2017.39.06, 2017.

Warny, S. A., Bart, P. J., and Suc, J.-P.: Timing and progression of climatic, tectonic and glacioeustatic influences on the Messinian Salinity Crisis, Palaeogeogr. Palaeocl., 202, 59-66, https://doi.org/10.1016/S0031-0182(03)00615-1, 2003.

Weijers, J. W. H., Schouten, S., Spaargaren, O. C., and Sinninghe Damsté, J. S.: Occurrence and distribution of tetraether membrane lipids in soils: Implications for the use of the $\mathrm{TEX}_{86}$ proxy and the BIT index, Org. Geochem., 37, 1680-1693, https://doi.org/10.1016/j.orggeochem.2006.07.018, 2006.

Westerhold, T., Röhl, U., Frederichs, T., Agnini, C., Raffi, I., Zachos, J. C., and Wilkens, R. H.: Astronomical calibration of the Ypresian timescale: implications for seafloor spreading rates and the chaotic behavior of the solar system?, Clim. Past, 13, 11291152, https://doi.org/10.5194/cp-13-1129-2017, 2017.

Whalen, M. T., Gulick, S. P. S., Pearson, Z. F., Norris, R. D., PerezCruz, L., and Urrutia-Fucugauchi, J.: Annealing the Chicxulub impact: Paleogene Yucatán carbonate slope development in the Chicxulub impact basin, Mexico, in: Deposits, Architecture, and Controls of Carbonate Margin, Slope and Basinal Settings, Special Publication-SEPM, Society for Sedimentary Geology, 105, 282-304, https://doi.org/10.2110/sepmsp.105.04, 2013.

Wing, S. L. and Currano, E. D.: Plant response to a global greenhouse event 56 million years ago, Am. J. Bot., 100, 1234-1254, https://doi.org/10.3732/ajb.1200554, 2013.

Wing, S. L., Harrington, G. J., Smith, F. A., Bloch, J. I., Boyer, D. M., and Freeman, K. H.: Transient floral change and rapid global warming at the Paleocene-Eocene boundary, Science, 310, 993-996, https://doi.org/10.1126/science.1116913, 2005.

Winguth, A., Shellito, C., Shields, C., and Winguth, C.: Climate Response at the Paleocene-Eocene Thermal Maximum to Greenhouse Gas Forcing - A Model Study with CCSM3, J. Climate, 23, 2562-2584, https://doi.org/10.1175/2009JCLI3113.1, 2010.

Zachos, J. C., Wara, M. W., Bohaty, S., Delaney, M. L., Petrizzo, M. R., Brill, A., Bralower, T. J., and Premoli-Silva, I.: A transient rise in tropical sea surface temperature during the Paleocene-Eocene thermal maximum, Science, 302, 1551-1554, https://doi.org/10.1126/science.1090110, 2003.

Zachos, J. C., Schouten, S., Bohaty, S., Quattlebaum, T., Sluijs, A., Brinkhuis, H., Gibbs, S. J., and Bralower, T. J.: Extreme warming of mid-latitude coastal ocean during the Paleocene-Eocene Thermal Maximum: Inferences from $\mathrm{TEX}_{86}$ and isotope data, Geology, 34, 737-740, https://doi.org/10.1130/G22522.1, 2006. 